\title{
Internet (Social Media) and Its Relationship with Hoax and Fake News in the 2019 Presidential Election
}

\author{
$1^{\text {st }} \mathrm{W}$ Syaputri \\ Universitas Indonesia \\ Jl. Margonda Raya, Pondok Cina, \\ Kecamatan Beji, Kota Depok, \\ Jawa Barat 16424, Indonesia \\ wurisyaputri@gmail.com \\ $4^{\text {th }}$ D Kasriyati \\ Universitas Lancang Kuning \\ Jalan Yos Sudarso No.KM. 8, Umban \\ Sari, Kec. Rumbai, Rumbai,Pekanbaru, \\ Riau 28266, Indonesia \\ $7^{\text {th }}$ Seftika \\ Universitas Muhammadiyah Pringsewu \\ J1. KH. Ahmad Dahlan No.112, \\ Pringsewu Bar., Kec. Pringsewu, \\ Kabupaten Pringsewu, Lampung 35373 \\ Indonesia
}

\author{
$2^{\text {nd }}$ L Septianasari \\ STKIP Muhammadiyah Bogor \\ Komplek Perguruan Muhammadiyah \\ Jln. Raya Leuwiliang No. 106 Kec. \\ Leuwiliang Kabupaten Bogor, \\ Indoensia \\ $5^{\text {th }}$ Episiasi \\ STKIP PGRI Lubuk Linggau \\ Jl. Mayor Toha, Air Kuti, Lubuk \\ Linggau Tim. I, Kota Lubuklinggau, \\ Sumatera Selatan 31625, Indoensia
}

\author{
$3^{\text {rd }}$ S Retnawati \\ Universitas Pamulang \\ Jl. Surya Kencana No.1, Pamulang \\ Bar., Kec. Pamulang, Kota Tangerang \\ Selatan, Banten 15417, Indonesia \\ $6^{\text {th }}$ Izhar \\ Universitas Muhammadiyah Pringsewu \\ Jl. KH. Ahmad Dahlan No.112, \\ Pringsewu Bar., Kec. Pringsewu, \\ Kabupaten Pringsewu, Lampung 35373 \\ Indonesia
}

\begin{abstract}
This research observe the Indonesia presidential election 2019 focused on massive hoax and fake news on social media. These phenomena are giving such effects for society because it leads emergence chaos. The objective of this research identified fake news and described language misuse on Indonesia presidential election 2019 to reduce emergence chaos in society. Readers who have good competence will be able to distinguish between factual reports and opinion pieces that tend to be subjective. On the other hand, incompetent readers will be easily provoked by fictitious issues that tend to be provocative. Method of the research used descriptive qualitative on referential and phenomenology approaches. Data collected using scrutinized (simak) method. The data got from www.turnbackhoax.id website. This website is used as a data source because the data contained on this page is accompanied by valid evidence related to fake news or hoax that are discussed on social media. The data analysed by using theories from Yule (2006) and Huang (2006) about presupposition on landscape discourse. The result shown, misused refer to criminal action did by certain people in spreading provocative issues. Those issues propagate narration with picture to lead the public opinion.
\end{abstract}

Keywords-Internet, Social media, Hoax, Fake News, Presidential Election

\section{INTRODUCTION}

Ministry of Communication and Information Indonesia limited media social access on May 22th-25th, 2019. This policy in order to prevent fake news and hoax dissemination that feared public space chaos relate with Indonesia Presidential election 2019 announcement result. Internet acts, ones is social media usage as the best medium for proliferation and diffusion of fake news [1]. Based on press conference number 92/HM/KOMINFO/04/2019 Ministry of Communication and Information identified 1.645 hoax are circulating in society relate with elections 2019. The data collected from August 2019 and validated. Some of those data was convicted because potentially divide the nation. Many provocative hoax and fake news are circulating in public space. Nearly $70 \%$ of people are concerned about the propagation of fake news [2]. These phenomena are bad consumption for society because it leads emergence chaos.

Language misuse on fake news and hoax ever occur in another election. This phenomenon occurred on another county such as on politic moments like on Brexit, U.K. and U.S. presidential election. The president candidate was Donald Trump as one of the president candidate on U.S. on 2016 was found some fake news and hoax were circulating in the wider community [3]. The fake news contents were 
various such as hoax and hate speech. Mass media and social media are the easiest places to spread fake news, hoax, or hate speech. Political issues are the most interesting domain to be subjected to criminalization of this kind of language.

This relates to the dirty political manoeuvres used to bring down the opposition. Readers who have good competence will be able to distinguish between factual reports and opinion pieces that tend to be subjective [4]. On the other hand, incompetent readers will be easily provoked by fictitious issues that tend to be provocative. The result, people are polarized into those who speaks positively or negatively [5]. There is a long way to go tackle the problem of fake news detection, transfer learning promises to be a strong means of progress in the field [6]. Furthermore, this article examines language abuse or language criminalization that appeared in the public sphere during the 2019 Indonesian Presidential election. The purpose of writing this paper is to describe the categories of fake news and to describe the forms of language abuse during the 2019 Elections in Indonesia.

\section{RESEARCH METHODS}

This qualitative research used referential approach and phenomenology achieved research objectives. Data collected using scrutinized (simak) method. The website www.turnbackhoax.id is used as a data bank. This website is used as a data source because the data contained on this page is accompanied by valid evidence related to fake news or hoax that are discussed on social media. Data is then taken by editing an image (screenshot). The collected data is then processed using presupposition theory [7].

\section{RESULT AND DISCUSSION}

\section{A. Fake News Categories}

Today, fake news is very easy to find in the digital era. Each individual can easily manipulate data and news content then disseminate the news through various platforms on internet sites. This activity is in order to achieve certain goals. In the lightest realm, the purposes of writing fake news are only for jokes or entertainment. However, in serious domains, fake news can be created by certain individuals with the aim of dividing the nation or including it as part of spreading propaganda issues.

Vasu et. al. has grouped this fake news into five categories [8]. The parameters of the grouping are based on motives or goals and the impact of writing fake news or hoax. The grouping includes:

Disinformation campaign to damage national security. In this section fake news is aimed at creating instability in national security in a country through community subversion, including in democratic processes such as elections. The more significant impact of this case is the shock of national security and social cohesiveness.

a. Misinformation for domestic political agenda

This category has a wide range of domains. The scope of this category includes viral rumours, semi-truth information, both by forming public opinion and by influencing political resilience through defamation of important figures in a country. Such cases are found in the U.S. Presidential Election. in 2016, especially in the
Donald Trump campaign section. A similar case also occurred in the Brexit referendum in U.K. ago.

b. Non-political misinformation with the aim of being viral

This form of misinformation is currently unrelated to politics, but the aim is to neutralize false news or hoaxes to create chaos. For example, related to an increase in the exchange rate when a disaster or war occurs somewhere. Another example is the terrorism attack in Manchester on 22 May 2017. In the aftermath of this incident there is a lot of fake news or hoaxes that are so viral on the internet, such as news about missing children, armed men outside the Royal Odham Hospital, and so on.

c. Lies for entertainment

The hoax or hoaxes in this section are intended only for entertainment or humour. The negative impact is that it is feared that there will be parties who believe in the jokes that the media make in this form. An example of this case is the onion article that was re-published by the People's Daily newspaper published in China. In the article mentioned that Kim Jong Un was selected as the sexiest man in the world in 2012.

d. Lies for financial gain

The case in this category is based on the motive to use the media in manipulating information to achieve additional income from advertising or sentiment that can free up manipulating market stock.

According to five categories it can be concluded that fake news or hoax have a negative impact. Although the level of loss incurred in each category is different, but the consequences arising from fake news and hoaxes have the potential to harm the patient's object. Therefore, the spreaders of fake news and hoax need to be dealt with firmly so that the deterrent effect arises towards the perpetrators. In addition, the need for systematic law enforcement, to deal with this so that people can be more careful in speaking.

B. Language Abuse during the 2019 Presidential Election in Indonesia

Since 2018, a lot of fake or hoax news has been spread on social networks. In this case the Ministry of Communication and Information has captured thousands of hoaxes that are spread in public spaces. Some of them have been criminalized by the Indonesian National Police. As with other criminal cases, criminalization of this kind of language really needs to be dealt with firmly. This is because the content of fake news, hoaxes, or hate speech has the potential for significant damage.Regarding the misuse of language on social media in the form of fake news and hoaxes, researchers used the theory of [7] (also see [9]) to analyse the data. The following data shows several dimensions of language abuse on social media during the 2019 Presidential Election. 


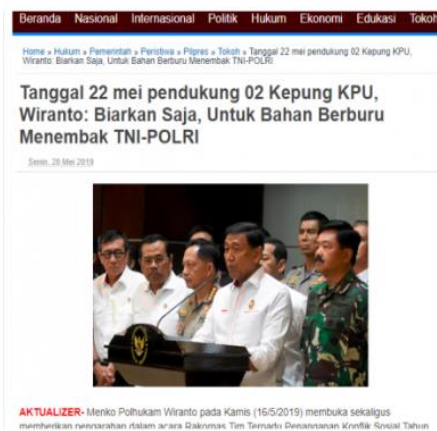

Fig. 1. Data 1 (Source:[10] )

On May 16, 2019, Wiranto gave direction in the National Coordination Meeting on the Integrated Team for Handling Social Conflict in 2019. On this occasion he gave direction to avoid post-election social conflict. However, the Actualize account (actuall.blogspot.com) on data (1) spread fake or hoax content that stated that Wiranto gave directions to TNI-POLRI to shoot 02 supporters who surrounded the KPU. The content of the data (1) contains false news that Wiranto gave directions to the TNI-Polri to shoot at civilians supporting 02 who surrounded the KPU. Fake news form from data (1) is in the form of provocative headlines. The presupposition from data (1) contains provocative and defamatory headlines supported by image profiteering to strengthen the fabrication of content.

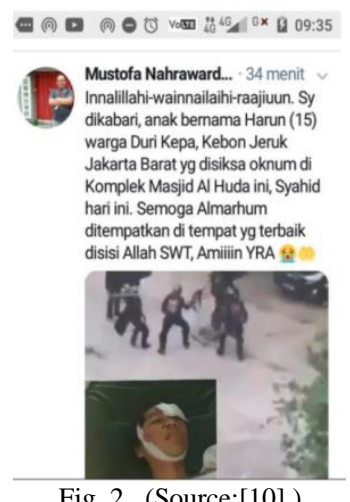

Fig. 2. (Source:[10] )

After the riots of May 22, 2019, circulating videos of the persecution were quite viral on social media. A netizen claimed that the man in the video was a child named Harun (15) who was allegedly a victim of riots. The content in the data (2) contains that a teenager named Harun who is 15 years old, a resident of West Jakarta, has been martyred because he was tortured by several persons in the Al Huda Mosque complex. The form of data (2) is in the form of an unverified statement. A cut of the victim's picture and video in the form of factual data, but the two have no correlation. The presuppositions from data (2) indicate that statements that are not accompanied by valid evidence and pieces of the image are used to lead public opinion that an innocent teenager has been brutally judged in this country of law.

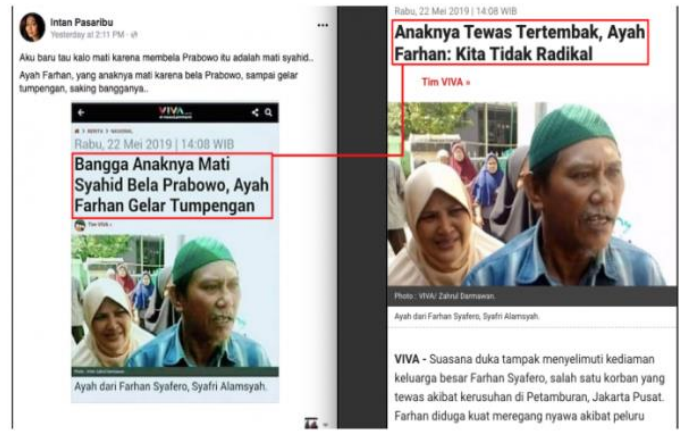

Fig. 3. Data 3 (Source: [10] )

Data (3) is still discussing similar cases of victims of the riots of May 22, 2019. The contents of the data (3) contain statements that the father of the victims of the riots of May 22, 2019 held a cone-shaped party as a manifestation of their pride in their son (Farhan) who was judged to have been martyred because defend Prabowo. The form of data (3) is in the form of editing and manipulating news headlines, spreading provocative speech and content that cannot be accounted for. The presumption from the data (3) of the edited headline suggests that defending Prabowo can be likened to martyrdom defending religion. The contents of such headlines seem to discredit elected presidential supporters and tend to politicize religious issues in the period of the political party.

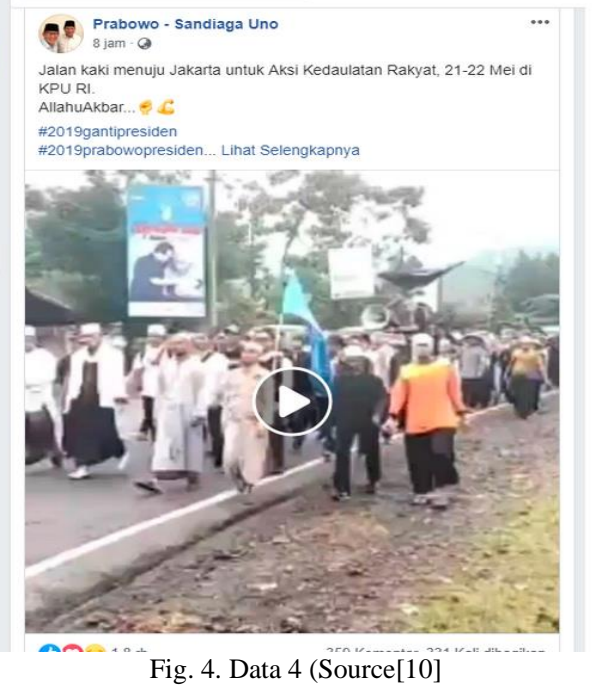

Data (4) presents fake content or hoaxes related to the action on May 22, 2019. The content of this data (4) contains claims that Tasikmalaya residents are taking part in a march on foot to Jakarta to participate in the People's Sovereignty action on 21-22 May 2019 in the Indonesian KPU. The form of data (4) is in the form of a false statement accompanied by an upload of the original video that was misused. Prejudice from data (4) in the form of public opinion overturning support for the action of people's sovereignty which led to riots in Jakarta on May 22, 2019. The facts of the investigation showed that the video was a video that had previously been uploaded on YouTube on November 28, 2018 under the title "Thousands Participants in the Tasikmalaya 212 Reunion Walk to Jakarta ". 


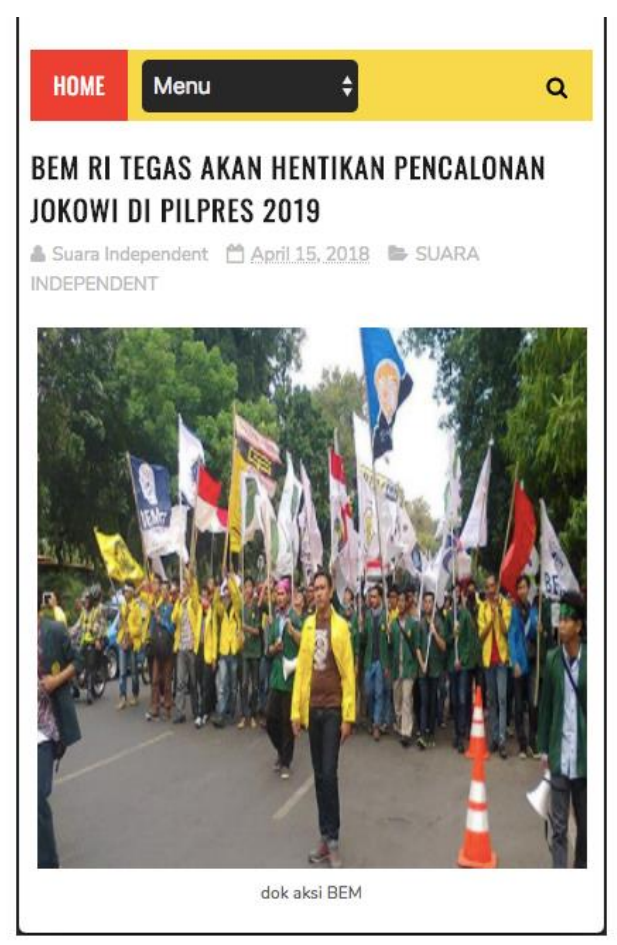

Fig. 5. Data 5 (Source: [10] )

The news manipulation model on data (5) is similar to the manipulation model on data (4), namely by using original photos that are misused to strengthen headline hoax. The content of the data (5) states that BEM RI firmly blocked Joko Widodo's nomination in the 2019 Presidential Election. The form of the data (5) is in the form of provocative headlines and original photos that are misused. The presumption to be highlighted in the false news in data (5) is to show that it is as if Indonesian young intellectuals did not approve of the re-nomination of Joko Widodo as a Presidential Candidate in the 2019 Election. The facts behind the photos in the data (5) are the photos in the article. is a photo of the JABOTABEK Students Eksecutive Board (BEM) that took the Long March to the State Palace in 2015.

From the description of the five data it can be concluded that the overall content of the data is in the form of news that cannot be accounted for and is not accompanied by valid evidence related to the statement submitted. Forms of fake news and hoaxes are artists of provocative speech, slander, and misuse of images and videos to reinforce lies. The entire data contains disinformation and misinformation related to the political issues of the 2019 Presidential Election.

\section{CONCLUSION}

Overall fake news or hoax can be grouped into 5 categories based on the contents of the content in the discourse. However, the entire category has the same characteristics, which contain information that is not in accordance with facts. The categories that have the greatest loss impact are misinformation and disinformation because they are aimed at leading public opinion. In the meantime, during the 2019 Election, there were a lot of hoaxes or fake news collected by the Ministry of Communication and Informatics and some of them were recorded on the website www.turnbackhoax.id. The data in this study indicate that the hoax spreaders intentionally manipulated information data, made use of original pictures and videos, and fabricated fake news to provoke the speech community.

The opinion that was led had a strong impact on supporters of the opposition and incumbent at the 2019 Democratic Party. Both camps gave each other hot balls through hoax and fake news with the aim of favouring each pair of candidates supported. As the speech community should be more careful in accepting information, both information leads to negative and positive opinion. It is hoped that the public will not be easily provoked and provoked massively without knowing the truth of news received.

\section{REFERENCES}

[1] Department of Computer Science and Engineering, Maulana Azad National Institute of Technology, Bhopal, 462003, India, S. Bauskar, V. Badole, P. Jain, and M. Chawla, "Natural Language Processing based Hybrid Model for Detecting Fake News Using Content-Based Features and Social Features," Int. J. Inf. Eng. Electron. Bus., vol. 11, no. 4, pp. 1-10, Jul. 2019, doi: 10.5815/ijieeb.2019.04.01

[2] "Kementerian Komunikasi dan Informatika." https://kominfo.go.id/content/detail/18321/siaran-pers-no92hmkominfo042019-tentang-kominfo-identifikasi-1645-hoaksterkait-pemilu-serentak-2019/0/siaran_pers (accessed Aug. 05, 2019).

[3] P. Bharadwaj and Z. Shao, "Fake News Detection with Semantic Features and Text Mining," Social Science Research Network, Rochester, NY, SSRN Scholarly Paper ID 3425828, Jul. 2019. Accessed: Jul. 11, 2020. [Online]. Available: https://papers.ssrn.com/abstract=3425828.

[4] A. Gelfert, "Fake news: A definition," Informal Log., vol. 38, no. 1, pp. 84-117, 2018

[5] M. A. Suriadi, The Language of Hoax: Explosive Growth of Fake News in the Biggest Muslim Society. Atlantis Press, 2019, pp. 7578.

[6] A. Aggarwal, A. Chauhan, D. Kumar, M. Mittal, and S. Verma, "Classification of Fake News by Fine-tuning Deep Bidirectional Transformers based Language Model," ICST Trans. Scalable Inf. Syst., vol. 0, no. 0, p. 163973, Jul. 2018, doi: 10.4108/eai.13-72018.163973.

[7] G. Yule, Pragmatics: Oxford University Press. Oxford, 1996.

[8] N. Vasu, B. Ang, T.-A. Teo, S. Jayakumar, M. Raizal, and J. Ahuja, Fake news: National security in the post-truth era. RSIS, 2018.

[9] Y. Huang, The Oxford handbook of pragmatics. Oxford University Press, 2017.

[10] "www.turnbackhoax.id - Penelusuran Google." https://www.google.com/search?q=\%3A+www.turnbackhoax.id \&rlz=1C1GGRV_enID857ID857\&oq=\%3A+www.turnbackhoa $\mathrm{x} . \mathrm{id} \& \mathrm{aqs}=$ chrome..69i57.1846j0j4\&sourceid=chrome\&ie=UTF8 (accessed Aug. 05, 2019). 